\title{
SARS-CoV-2 impact on oral health: a general view
}

\author{
Israel Parra-Ortega ${ }^{1}$ and Daniel Rodriguez-Ortega ${ }^{2,3 *}$ \\ ${ }^{1}$ Laboratorio Clínico, Hospital Infantil de México Federico Gómez; ${ }^{2}$ Laboratorio Clínico, Unidad de Medicina Familiar 5, Instituto Mexicano del Seguro \\ Social; ${ }^{3}$ Centro Interdisciplinario de Ciencias de la Salud (CICS UST), Instituto Politécnico Nacional. Mexico City, Mexico
}

\begin{abstract}
Coronavirus disease 2019 (COVID-19) is a new disease caused by the severe acute respiratory syndrome coronavirus 2 (SARS-CoV-2) virus. China reported the first case of COVID-19 in December 2019, and a few months later, the World Health Organization declared it as a pandemic. Oral ulcers in adult patients have been associated with COVID-19. However, no cases have yet been documented in children. The angiotensin-converting enzyme-2 (ACE2) receptor has been identified in tissues of the oral cavity. Studies have identified the tongue as the site with the highest expression of ACE2, and the oral epithelium, gingival epithelium, and salivary glands as sites of lesser extent expression. ACE2 expression is lower in children and varies with age. SARS-CoV-2 in saliva has been identified in various studies, which suggests that this could be a useful sample for diagnosis. However, its presence in saliva would indicate the high risk of contagion of this fluid.
\end{abstract}

Key words: SARS-CoV-2. COVID-19. Angiotensin-converting enzyme II. Children.

\section{Impacto del SARS-CoV-2 en la salud oral: una visión general}

\section{Resumen}

La COVID-19 es una nueva enfermedad causada por el SARS-CoV-2 (coronavirus tipo 2 del síndrome respiratorio agudo grave). El primer caso de COVID-19 se reportó en China en diciembre de 2019, y unos meses después la Organización Mundial de la Salud la declaró como una pandemia. En pacientes adultos se han asociado úlceras orales a la COVID-19; en niños aún no se han documentado casos. El receptor de la enzima convertidora de la angiotensina 2 (ECA2) se ha identificado en tejidos de la cavidad oral. Los estudios han identificado que la lengua es el sitio con mayor expresión del receptor de la ECA2, y el epitelio bucal, el epitelio gingival y las glándulas salivales lo son en menor medida. La expresión de la ECA2 es menor en los niños y va aumentando con la edad. En diversos estudios se ha identificado el SARS-CoV-2 en la saliva, lo que sugiere que podría ser una muestra útil para el diagnóstico de este virus. Sin embargo, su presencia en saliva indicaría un alto riesgo de contagio de este fluido.

Palabras clave: SARS-CoV-2. COVID-19. Enzima convertidora de la angiotensina 2 (ECA2). Niños.

\section{Correspondence:}

*Daniel Rodríguez Ortega

E-mail: dan_rodr14@me.com
Date of reception: $25-06-2020$

Date of acceptance: 28-06-2020

DOI: 10.24875/BMHIM.20000192
Available online: $26-01-2021$

Bol Med Hosp Infant Mex. 2021;78(2):91-94 www.bmhim.com 1665-1146/@ 2020 Hospital Infantil de México Federico Gómez. Published by Permanyer. This is an open access article under the CC BY-NC-ND license (http://creativecommons.org/licenses/by-nc-nd/4.0/). 


\section{Introduction}

Coronavirus disease 2019 (COVID-19) is an infectious disease caused by a recently discovered coronavirus, severe acute respiratory syndrome coronavirus 2 (SARS-CoV-2). In December 2019, a case series was reported and confirmed in Wuhan, China ${ }^{1,2}$. On March 11, 2020, the World Health Organization declared it as a pandemic ${ }^{3}$.

This disease can cause mild symptoms or cause progressive respiratory failure in adult patients, leading to death ${ }^{2}$. The most frequently reported signs and symptoms in a study involving 138 hospitalized patients in Wuhan, China, included fever (98.6\%) and fatigue (69.6\%). Other documented symptoms are dry cough, diarrhea, nausea, dizziness, vomiting, headache, myalgia, and dyspnea ${ }^{4,5}$.

Mild clinical manifestations occur in most of the pediatric population. The course of the disease is short and has a better prognosis compared with adolescents and adults. In children, the main COVID-19 symptoms are fever, dry cough, pharyngeal erythema, and fatigue. Breathing difficulties are rare, even in moderate or severe pathological conditions $s^{6-9}$. The duration of the fever can be from 2 to 3 days and up to 8 days $^{10}$. Other associated symptoms are diarrhea, rhinorrhea, and vomiting ${ }^{11}$.

The virus can be transmitted from person to person (through direct inhalation of microdroplets spread by sneezing, coughing, or speaking) and by direct contact with contaminated surfaces (self-dissemination through nasal, oral, and ophthalmic mucosa $)^{12}$.

\section{Oral signs associated with COVID-19}

Cases of oral and skin signs in adults due to SARSCoV-2 have been documented. In Italy, a report from the Hospital Lecco informed that, out of 88 confirmed patients, 18 (20.4\%) developed skin signs, which included erythematous rash (14 patients), generalized urticaria (three patients), and chickenpox-like vesicles (one patient), all of them with a tendency directed to the trunk ${ }^{13}$. In Spain, cases of oral signs associated with SARS-CoV-2 have been reported, depicting lesions such as ulcers or ampules in the oral cavity ${ }^{14}$. Another report documented three patients with macules and petechiae on the palate ${ }^{15}$. In France, a patient was reported with tongue inflammation during the first $24 \mathrm{~h}$, with subsequent evolution to an erythematous macula, which resulted in an irregular and asymptomatic ulcer. The lesion probably derived from an inflammatory reaction triggered by vasculitis caused by COVID$19^{16,17}$. More information is needed to confirm and better understand the involvement of SARS-CoV-2 in oral cavity signs. No cases with an association between oral signs and COVID-19 in the pediatric population have been reported.

\section{Expression of the angiotensin-converting enzyme 2 receptor on oral mucosal epithelial cells}

Transmission of SARS-CoV-2 can occur orally with saliva droplets or through nasal secretions in symptomatic and asymptomatic patients. The infection starts with the binding of the virus to the surface of the host cell. The spike protein (S) enables the virus to enter the target cell by binding its surface subunit $S 1$ to the host cell's angiotensin-converting enzyme 2 (ACE2) receptor $^{18}$. Therefore, cells expressing ACE2 can act as target cells and are highly susceptible to SARS-CoV-2 infection. The $S$ protein binds to ACE2 and is activated by the serine transmembrane protease 2. High expression of this enzyme has been identified in different areas of the human body, such as in pulmonary alveolar epithelial cells type II (AT2), upper esophagus stratified epithelium, ileum, and colon enterocytes, cholangiocytes, myocardial cells, oral cavity mucosa, proximal kidney tubule cells, and urothelial cells of the bladder ${ }^{19}$.

Taste alteration has been reported as an early sign of SARS-CoV-2 infection in adults ${ }^{20,21}$. Expression of ACE2 is the main factor for viral entry into the host cell in SARS-CoV-2 infection. ACE2 is expressed in epithelial cells from different sites in the oral cavity. The highest expression was found in the tongue and lesser amounts in the oral and gingival tissue ${ }^{19}$. Expression of ACE2 has also been detected in salivary glands ${ }^{22}$, which could identify the oral cavity as a highly susceptible site for SARS-CoV-2 infection. Although the mechanism for the alteration in the perception of taste by this coronavirus is not clear, this symptom could be considered an early manifestation in infected adults. No cases of taste alteration associated with COVID-19 have been reported in children.

In a North American cohort that included 305 patients from 4 to 60 years old, it was determined that the ACE2 expression was lower in patients between 4 and 9 years old compared with adults and adolescents ${ }^{23}$. In younger patients, the risk of lung inflammation and injury from COVID-19 may also be lower ${ }^{24,25}$. 


\section{Saliva as a diagnostic test for SARS- CoV-2}

Diagnostic tests for COVID-19 are critical for controlling the pandemic within communities and hospitals in every country. The most used sample for the reverse transcription polymerase chain reaction is the oropharyngeal and nasopharyngeal swab. Saliva samples contain secretions from the upper and lower airways, plus saliva from the salivary glands ${ }^{26}$. One study indicated that $87 \%$ of patients who tested positive for SARS-CoV-2 using nasopharyngeal and oropharyngeal swabs also tested positive in saliva ${ }^{27}$. Another study indicated that $91.7 \%$ of infected patients tested positive in saliva ${ }^{28}$.

The saliva test contains several advantages, including reduction of the exposure risk for the health care worker by avoiding the obtaining of a nasal or oropharyngeal sample, which could cause the patient to cough or sneeze, thus dispersing microparticles; it also reduces discomfort for the patient and reduces the number of consumables required ${ }^{29}$.

Disorders of the oral cavity caused by SARS-CoV-2 are not yet evident. However, documented cases are associated with viral vasculitis, although more studies are needed.

ACE2 receptor is essential for the entrance of this virus into the host cell and has been found in several body tissues, which may indicate the high risk of these tissues to be infected. The expression of this receptor is lower in children than in the adult population and increases with age, which could be comparatively involved with less clinical signs and reduced periods of illness of COVID-19 in children.

It has been described that saliva may be a route of SARS-CoV-2 transmission and has been investigated as a candidate for viral determination because, the SARS-CoV-2 test in this fluid is positive in most COVID19 patients. Advantages of a saliva-based diagnostic method includes reduced exposure risk for health care workers, low invasiveness, and high accessibility.

\section{Ethical disclosures}

Protection of human and animal subjects. The authors declare that no experiments were performed on humans or animals for this study.

Confidentiality of data. The authors declare that they have followed the protocols of their work center on patient data publication.
Right to privacy and informed consent. The authors declare that no patient data appear in this article.

\section{Conflicts of interest}

The authors declare no conflicts of interest.

\section{Funding}

None.

\section{References}

1. Chan JF, Yuan S, Kok KH, To KK, Chu H, Yang J, et al. A familial cluster of pneumonia associated with the 2019 novel coronavirus indicating person-to-person transmission: a study of a family cluster. Lancet. 2020;395:514-23.

2. Zhou $P$, Yang XL, Wang XG, Hu B, Zhang L, Zhang W, et al. A pneumonia outbreak associated with a new coronavirus of probable bat origin. Nature. 2020;579:270-3.

3. Cucinotta D, Vanelli M. WHO declares COVID-19 a pandemic. Acta Biomed. 2020;91:157-60.

4. Wu YC, Chen CS, Chan YJ. The outbreak of COVID-19: an overview J Chin Med Assoc. 2020;83:217-20.

5. Wang D, Hu B, Hu C, Zhu F, Liu X, Zhang J, et al. Clinical characteristics of 138 hospitalized patients with 2019 novel coronavirus-infected pneumonia in Wuhan, China. JAMA. 2020;323:1061-9.

6. World Health Organization. Report of the WHO-China Joint Mission on Coronavirus Disease 2019 (COVID-19). Geneva: World Health Organization; 2020. Available from: https://www.who.int/docs/default-source/coronaviruse/who-china-joint-mission-on-covid-19-finalreport.pdf

7. Lyu J, Miao T, Dong J, Cao R, Li Y, Chen Q. Reflection on lower rates of COVID-19 in children: does childhood immunizations offer unexpected protection? Med Hypotheses. 2020;143:109842.

8. Guan WJ, Ni ZY, Hu Y, Liang WH, Ou CQ, He JX, et al. Clinical characteristics of coronavirus disease 2019 in China. N Engl J Med. 2020;382:1708-20.

9. Liu W, Zhang Q, Chen J, Xiang R, Song H, Shu S, et al. Detection of COVID-19 in children in early January 2020 in Wuhan, China. N Engl J Med. 2020;382:1370-1.

10. Chen X, Ling J, Mo $P$, Zhang $Y$, Jiang $Q$, Ma Z, et al. Restoration of leukomonocyte counts is associated with viral clearance in COVID-19 hospitalized patients, medRxiv; 2020. Preprint not peer-reviewed.

11. Dong $\mathrm{Y}, \mathrm{Mo} \mathrm{XI}, \mathrm{Hu} \mathrm{Y}, \mathrm{Qi} \mathrm{X}$, Jiang $\mathrm{F}$, Jiang $Z$, et al. Epidemiological characteristics of 2143 pediatric patients with 2019 Coronavirus disease in China. Pediatrics. 2020;145:e20200702.

12. Xu R, Cui B, Duan X, Zhang P, Zhou X, Yuan Q. Saliva: potential diagnostic value and transmission of 2019-nCoV. Int J Oral Sci. 2020;12:11.

13. Recalcati S. Cutaneous manifestations in COVID-19: a first perspective. J Eur Acad Dermatol Venereol. 2020;34:e212-3.

14. Carreras-Presas M, Sánchez A, López-Sánchez A, Jané-Salas E, Somacarrera P. Oral vesiculobullous lesions associated with SARS-CoV-2 infection. Oral Dis. 2020; Oral Dis. 2020;00:1-3.

15. Jimenez-Cauhe J, Ortega-Quijano D, Carretero-Barrio I, Suarez-Valle A, Saceda-Corralo D, Moreno-Garcia Del Real C, et al. Erythema multiforme-like eruption in patients with COVID-19 infection: clinical and histological findings. Clin Exp Dermatol. 2020;45:892-5.

16. Chaux-Bodard, AG, Deneuve S, Desoutter A. Oral manifestation of COVID-19 as an inaugural symptom? J Oral Med Oral Surg. 2020;26:18.

17. Madjid M, Safavi-Naeini P, Solomon SD, Vardeny O. Potential effects of Coronaviruses on the cardiovascular system: a review. JAMA Cardiol. 2020;5:831-40.

18. Vinayachandran D, Balasubramanian S. Salivary diagnostics in COVID-19: future research implications. J Dent Sci. 2020;15:364-6.

19. Xu H, Zhong L, Deng J, Peng J, Dan H, Zeng X, et al. High expression of ECA2 receptor of $2019-n \mathrm{CoV}$ on the epithelial cells of oral mucosa. Int J Oral Sci. 2020;12:8.

20. Hjelmesæth J, Skaare D. Loss of smell or taste as the only symptom of COVID-19. Tidsskr Nor Laegeforen. 2020;140:10.

21. Chen L, Zhao J, Peng J, Li X, Deng X, Geng Z, et al. Detection of SARSCoV-2 in saliva and characterization of oral symptoms in COVID-19 patients. Cell Prolif. 2020;53:e12923. 
Bol Med Hosp Infant Mex. 2021;78(2)

22. Song J, Li Y, Huang X, Chen Z, Li Y, Liu C, et al. Systematic analysis of ACE2 and TMPRSS2 expression in salivary glands reveals underlying transmission mechanism caused by SARS-CoV-2. J Med Virol. 2020;92:2556-66

23. Patel A, Verma A. Nasal ECA2 levels and COVID-19 in children. JAMA 2020;323:2386-7.

24. Schouten L, Helmerhorst H, Wagenaar G, Haltenhof T, Lutter R, Roelofs $\mathrm{JJ}$, et al. Age-dependent changes in the pulmonary renin-angiotensin system are associated with severity of lung injury in a model of acute lung injury in rats. Crit Care Med. 2016;44:e1226-35.

25. Bunyavanich S, Do A, Vicencio A. Nasal gene expression of angiotensin-converting enzyme 2 in children and adults. JAMA. 2020;323:2427-9.
26. Sri S, Parmar R, Anand H, Srikanth $\mathrm{K}$, Saritha M. A review of salivary diagnostics and its potential implication in detection of COVID-19. Cureus. 2020;12:e7708.

27. To K, Tsang O, Leung W, Tam A, Wu T, Lung D, et al. Temporal profiles of viral load in posterior oropharyngeal saliva samples and serum antibody responses during infection by SARS-CoV-2: an observational cohort study. Lancet Infect Dis. 2020;20:565-74.

28. Xu J, Li Y, Gan F, Du Y, Yao Y. Salivary glands: potential reservoirs for COVID-19 asymptomatic. J Dent Res. 2020;99:989.

29. Williams E, Bond K, Zhang B, Putland M, Williamson DA. Saliva as a noninvasive specimen for detection of SARS-CoV-2. J Clin Microbiol. 2020;58:e00776-20. 